\title{
Orta Asya Türk Cumhuriyetlerinin Ekonomik Performansının Hollanda Hastalığı Yönünden İncelenmesi
}

\author{
Sevgi Sezer ${ }^{a}$
}

\begin{abstract}
Öz: Ekonomi için yararlı gelişmelerin zamanla zararlı sonuçlar vermeye başlamasını ifade eden Hollanda Hastalığı, özellikle doğal kaynak zengini ülkelerde görülebilmektedir. Sahip oldukları petrol ve doğal gaz gibi kaynaklar sayesinde yüksek gelir elde ederek bugüne kadar gelen Orta Asya Türk Cumhuriyetleri de acaba ileride böyle bir sorunla karşılaşır mı? Eğer böyle bir risk varsa, çözüm önerileri ve alınması gereken tedbirler nelerdir? Makalede bu sorulara cevap aranmaktadır. Çalışmada 1998-2015 dönemi için panel veri analizi yapılmıştır. Ülkeler arasında yatay kesit bağımlılığının tespit edildiği çalışmada, serilerin durağanlığı çoklu yapısal kırılmalı PANKPSS testiyle incelenmiş ve serilerin düzeyde durağan oldukları belirlenmiştir. Regresyon analizlerinde Hollanda Hastalığının varlığıyla ilgili kesin bir sonuca ulaşılamamıştır. Seriler arasındaki nedensellik ilişkileri, Dumitrescu ve Hurlin (2012) yöntemiyle incelenmiş ve bu ülkelerde Hollanda Hastalığının var olduğu yönünde kanıtlar elde edilmiştir. Çalışma kapsamında, doğal kaynak ihracatına dayalı ekonomik modellerin taşıdığı riskler ve alınması gereken tedbirler, dünyadaki iyi uygulamalar eşliğinde açıklanmıştır. Çalışmanın, ilgili ülke politikacılarının dikkatini bir kez daha bu konuya çekerek, geç olmadan gerekli tedbirleri almalarına ve sürdürülebilir, yüksek bir ekonomik büyüme modeline geçmelerine katkı sağlaması beklenmektedir.
\end{abstract}

Anahtar Sözcükler: Orta Asya Türk Cumhuriyetleri, Doğal Kaynak Ihracat, Hollanda Hastalığı

JEL Sınıflandırması: N55, O13, Q01

\section{Investigating The Economic Performance of Central Asian Turkic Republics in Terms of Dutch Disease}

\begin{abstract}
The Dutch Disease, which means that beneficial developments for an economy begins to give harmful results over time, can be seen especially in the countries having rich natural resources. Will the Central Asian Turkic Republics, which have achieved high income thanks to their resources such as oil and natural gas, come to such a problem in the future? If there is such a risk, what would be the solutions and the measures to be taken? In this paper, the answers of these questions are sought. In this study, a panel data analysis applied for 1998-2015 periods. Determining crosssectional dependence, stationarity of the series was examined by PANKPSS test with multiple structural breaks and it is found that the series are stationary at level. In regression analysis, a clear result could not be obtained about the existence of Dutch Disease. Causality relations among the series were investigated by Dumitrescu and Hurlin (2012) method and results implying the existence of Dutch Disease in these countries were obtained. In the study, risks of economic models based on natural resources export and required precautions are explained with good application examples around the world. It is expected that the attention of policymakers of related countries will be drawn on this issue in order them to impose required precautions to have a sustainable and high economic growth.
\end{abstract}

Keywords: Central Asian Turkic Republics, Natural Resources Export, Dutch Disease

JEL Classification: N55, O13, Q01 


\section{Giriş}

1959 'da Schlohteren bölgesinde büyük doğalgaz rezervleri keşfedilen Hollanda, kısa sürede önemli bir doğalgaz ihracatçısı olmuştur. Zamanla Hollanda'nın doğal gaz ihracat ve toplam ihracat gelirleri hızla artarken, bütün yatırımlar bu sektöre yönelmiş ve diğer alanlarda sanayisizleşme ve gerileme yaşanmıştır (Corden ve Neary, 1982). Gelen bol miktardaki dövizle birlikte ülke parası aşırı değerlenmiş, ihracat düşmeye, ithalat artmaya başlamıştır (Ebrahimzadeh, 2012). Doğal kaynak ihracatına bağlı yaşanan bu olumsuz duruma, literatürde Hollanda Hastalığı adı verilmiştir (The Economist, 2014). Geçmiş yıllarda gül ihracatı nedeniyle Moğolistan ve kahve ihracat nedeniyle Yemen ve Kolombiya da Hollanda Hastalığına benzer problemler yaşamıştır (Şahin ve Kutluay Şahin, 2015).

Büyük miktarda doğal kaynak keşfi veya doğal kaynak fiyatlarındaki artışlar, hükümetlere verimli biçimde yönetebileceklerinden daha fazla ihracat geliri sağlamaktadır. Bu geliri iyi yönetemeyen ülkeler, uzun dönemde bu kaynaklardan faydadan çok zarar görebilmektedir (Gelb, 1988). Oysa elde edilen gelirler, yeni yatırımlara, araştırma-geliştirme (Ar-Ge) faaliyetlerine, eğitim ve sağlık harcamalarına yönlendirilebilirse, ülkede istihdam, teknoloji, ürün çeşitliliği ve üretim düzeyi artacak, ekonomik büyüme ve kalkınma hızlanacaktır. Bu konuda izlediği petrol fonu yönetimi ve Ar-Ge'ye dayalı alternatif ekonomik faaliyetleri ile Norveç, Orta Asya Türk Cumhuriyetleri ve diğer doğal kaynak zengini ülkeler için güzel bir örnektir. Rusya ve Arabistan'dan sonraki en büyük petrol ihracatçısı olmasına karşın Norveç'in Hollanda Hastalığı riski taşımamasının nedeni; petrol ve doğal gaz rezervlerinin, kamu malı olarak kanunlarla koruma altına alınmış olması ve kurulan petrol fonudur. Petrol ve doğal gaz gelirlerinin \%80'ini bu fona devredilirken, fonun yönetimi de Merkez Bankası'na bırakılarak, siyasilerin fonu politik amaçları doğrultusunda kullanmalarının önü alınmıştır. Norveç'te çok olağandışı bütçe açıkları meydana geldiğinde, sınırlı kez, hükümetin bu fondan kullanmasına izin verilmiştir. Büyüklüğü bir trilyon dolara yaklaşan fondaki paralar, yurtdışında tahvil ve borsa yatırımlarıyla değerlendirilmektedir. Bu nedenle Norveç, petrol ihraç eden diğer ülkelerin yaşadığı finansal problemlerden kaçınmayı başarabilmiştir (Sevinçer, 2009).

Orta Asya Türk Cumhuriyetleri, 1990'ların başlarında Sovyetler Birliğinden ayrılıp, bağımsız birer devlet haline geldikten sonra, Çin veya Güney Kore gibi hızlı bir ekonomik büyüme ve kalkınma gösterememiştir. Oysa bu ülkeler dünyadaki petrolün \%4'üne, doğal gazının \%5'ine sahip (Demirtepe, 2008) olmaları yönüyle, ekonomik büyümede önemli bir itici güce sahiptirler. Bu ülkeler şimdiye kadar büyük oranda doğal kaynakların doğrudan satımıyla ekonomik büyümelerini sağlamışlardır. Bu doğal kaynaklar, doğru yönetilemediğinde, Hollanda örneğinde de olduğu gibi ülkelere yarar yerine zarar da verebilecektir (Mercan ve Göçer, 2014). Özellikle doğal kaynakların işlenmeden satılması ve elde edilen gelirin belirli zümreler tarafindan kullanılıp, geniş halk kitlelerinin bundan mahrum bırakılması, Arap Baharı olaylarında görüldüğü üzere yaygın işsizliğe, gelir dağılımı dengesizliklerine ve sosyal patlamalara yol açabilmektedir (Göçer ve Çınar, 2015). Bu nedenle, devleti yönetenlerin dikkatli davranmaları, doğal kaynakların ortak bir kamu malı olduğu gerçeğini, bu kaynaklarda sadece şimdiki nesillerin değil, gelecek nesillerin de haklarının olduğunu unutmadan, sürdürülebilir politikalar geliştirmeleri gerekmektedir.

Doğal kaynak ihracatına dayalı ekonomileri bekleyen en önemli risklerden biri de zamanla bu kaynakların biteceğidir. Örneğin; doğalgaz rezervleri hızla azalmakta olan Hollanda'nın 2020-2025 yıllarında doğalgaz ihracatçısı olmaktan çıkıp, doğalgaz ithalatçısı haline gelmesi beklenmektedir (Erkut, 2015). Bu intimale karşı ülkelerin zamanında önlem almalarında yarar vardır. Dubai bu konuda güzel bir örnektir. 2001 'de petrol rezervlerinin azalmaya başladığını ve 2016'da biteceğini gören ülke yöneticileri, yeni gelir alanları oluşturma çabasına girmiş, ülkeyi turizm ve ticaret merkezi haline getirmeye karar vermiştir. 2004 yılında 5.5 milyon olan toplam turist sayısının 2010 yılına kadar 15 milyon kişiye çıkarılması hedeflenmiştir. Ancak ülkenin 72 km'lik sahilin bu kadar turiste yetmeyeceği görülmüş, bunun üzerine denizde suni adalar oluşturulması fikri benimsenmiştir. 2001-2008 döneminde inşa edilen Dubai Palmiye Adaları ve Dubai Dünya Adası sayesinde Dubai'nin sahil şeridi \%2118 artrılarak 1500 km'ye çıkarılmıştı (National Geographic, 2013). Ayrıca ülkede düzenlenen Dubai Alışveriş Festivali, Klasik Çöl Golf Turnuvası, Dubai Yaz Sürprizleri ve Dubai Dünya Kupası gibi etkinliklerle de kitle turizmi hedeflenmiştir (Onur, 2011). 
Bu çalışmanın amacı; Orta Asya Türk Cumhuriyetleri'nde Hollanda Hastalığı riskinin varlığını, 1998-2015 dönemi verileriyle panel veri yöntemiyle analiz etmektir. Çalışmanın ikinci bölümünde konunun teorik çerçevesine, üçüncü bölümde ülkelerin makroekonomik görünümüne, dördüncü bölümde literatür özetine yer verilmiş, beşinci bölümde ekonometrik analiz gerçekleştirilmiş, altıncı bölümdeki sonuç ve politika önerileriyle çalışma tamamlanmıştır. Çalışmanın, Orta Asya Türk Cumhuriyetleri ve diğer doğal kaynak zengini ülkelerin dikkatini bir kez daha Hollanda Hastalığı riskine çekerek, gerekli önlemleri almalarını hatrlatması beklenmektedir. Çalışmanın, incelenen konu, ülke sepeti, gerçekleştirilen ekonometrik analizler ve sunduğu politika önerileriyle literatüre katkı sağlayacağı değerlendirilmektedir. Bu çalışmanın literatüre bir başka katkısı da çalışmada kullanılan bütün verilerin alındıkları kaynakların bütün detayıyla paylaşılması, linklerinin sonraki araştırmacıların kullanımına sunulmasıdır.

\section{Teorik Çerçeve}

Doğal kaynak ihracatına bağı ekonomilerde, döviz kurlarındaki aşırı oynaklık ve reel döviz kurunun aşırı artması, ihracat performansını ve ekonomik büyümeyi negatif etkilemekte ve Hollanda Hastalığına neden olabilmektedir (Magud ve Saso, 2014). Doğal kaynak ihracat ve buradan elde edilen gelirler iyi yönetilemezse, ülkeye yarardan çok zararı olabilmektedir. Hollanda'da 1970'li yıllarda yaşanan durum budur. 1970-1977 arasında Hollanda'da işsizlik \%1.1'den \%5.1'e yükselmiştir (The Economist, 2014). Doğalgaz sektöründeki yüksek karlılı̆ı gören firmalar, diğer sektörlerdeki yatırımlarını bırakıp, doğal gaz sektörüne yönelmişler, diğer sektörlerde yatırımlar durma noktasına gelmiş ve bu sektörlerin ihracattaki payları düşmüştür. Bu durum, 1977 yılında Ekonomist dergisi tarafindan Hollanda Hastalığı olarak adlandırımış ve literatürde bu şekliyle anılmaya başlanmıştır.

Hollanda Hastalığı temelde; bir ülkede doğal kaynak sektörünün gelişmesiyle, diğer sektörlerin önemini kaybetmesini ifade etmektedir (Şahin ve Kutluay Şahin, 2015). Hollanda ekonomisine yön verenlerin zamanında müdahalesiyle ekonomide çeşitlilik artrılmaya, sera tarımı, kesme çiçekçiliğe, Ar-Ge ve inovasyona önem verilmeye başlanmıştır. Bu çabalar sonucunda 2015'ki 618 milyar dolarlık ihracatiyla Hollanda dünyanın 9. (World Bank, 2017b), 750 milyar dolarlık GSYH'siyle de dünyanın 17. büyük ekonomisi (World Bank, 2017c) durumuna gelmiştir. Hızla artan doğal kaynak ihracatının ekonomiye zararları Şekil 1'de gösterilmiştir:

Şekil 1. Hızla Artan Doğal Kaynak ihracatının Ülke Ekonomisine Etkileri

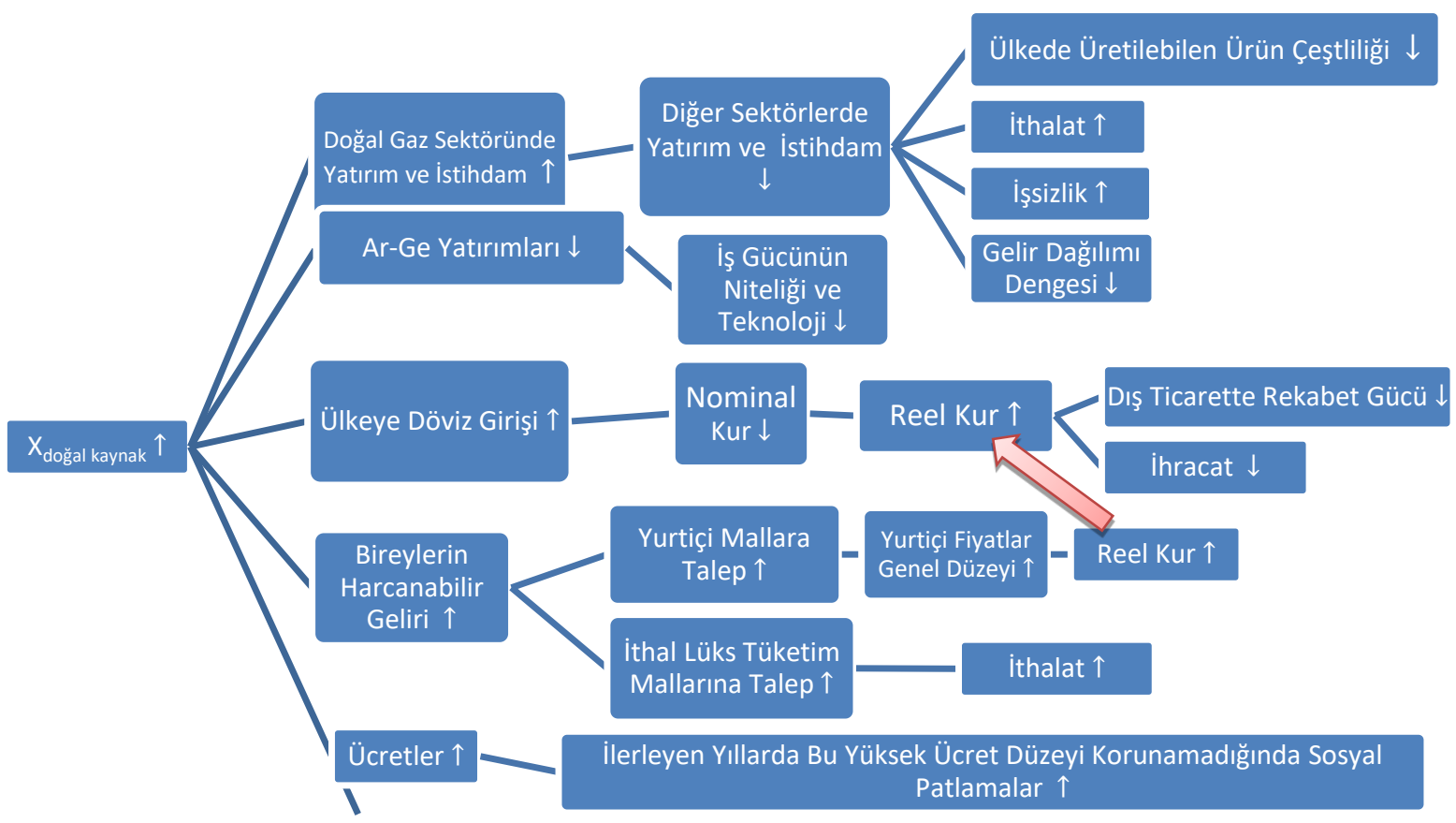

Kaynak: Konuyla ilgili literatür kullanılarak, tarafımızdan oluşturulmuştur. Not: X; ihracatı, yukarı ok; artışları, aşağı ok; azalışları ifade etmektedir. 
Şekil 1'den de görüldüğü üzere, bir ülkeye doğal kaynak ihracatnna bağlı olarak büyük miktarda döviz girmeye başlamasıyla oluşabilecek zararlı etkilerden birincisi; doğal kaynak sektörünün sahip olduğu yüksek getiri, diğer sektörlere yapılacak yatırımların bu alana kaydırılmasına ve diğer sektörlerin gerilemesine yol açabilecektir. Bu durum, üretilebilen ürün çeşidini azaltacak, ithalata bağımlılığı artıracak, bu sektörlerde çalışanların işsiz kalmasına, gelirlerinin düşmesine ve ülkede gelir dağılımının bozulmasına yol açacaktır.

Doğal kaynak ihracatyla yüksek karlılık elde edildiği dönemlerde Ar-Ge ve inovatif çabalara gerek görülmeyecek, bu da ülkedeki nitelikli işgücünü, bilgi birikimini ve teknolojik seviyeyi azaltacaktır.

Doğal kaynak ihracatının üçüncü zarar kanalı; ülkede oluşan döviz bolluğu ülke parasını değerli hale getirip, reel kurların yükselmesine, ülkenin dış ticaret rekabet gücünün azalmasına neden olacaktır (Mankiw, 2010). Reel döviz kuru (REXR) aşağıdaki formülle hesaplanmaktadır:

$$
R E X R=\frac{P^{d}}{E X R \cdot P^{f}}
$$

Burada $E X R$; nominal döviz kuru, yani bir birim yabancı paranın, ulusal para cinsinden karşılığıdır. $P^{d}$; yurtiçi, $P^{f}$; yurtdışı fiyatlar genel düzeyini ifade etmektedir. Ülkedeki döviz miktarı arttğında, nominal kur düşer, reel döviz kur artar. Reel kur atı̧ı ülkenin dış ticaret rekabet gücünü azaltır (Yıldırım, Karaman ve Taşdemir, 2009). İhracat düşer, ithalat artar, dış ticaret dengesi bozulur.

Artan doğal kaynak ihracatının ülke ekonomilerine dördüncü zarar verme kanalı ise; artan kişi başına düşen harcanabilir gelirle birlikte, bir yandan yurtiçinde mal ve hizmetlere olan talep artş̧ıla birlikte yurtiçi fiyatlar genel düzeyi $\left(P^{d}\right)$ artarak reel kurun yükselmesine ve ülkenin dış ticarette rekabet gücünün azalmasına yol açarken, diğer taraftan da bireylerin ithal lüks tüketim malları talebinin artması ile ülkenin ithalat hızla artmaya başlamasıdır (Hasanov ve Samadova, 2010).

Artan doğal kaynak ihracatının beşinci muhtemel zararı da; artan kamu gelirleriyle birlikte kamuda çalışan bireylerinin ücretlerine yüksek oranda zam yapılması, ancak bu durumun sonsuza kadar sürdürülememesidir. Doğal kaynakların azalması ya da fiyatının düşmesine bağıı olarak doğal kaynaktan elde edilen gelir azaldığında, devlet yüksek ücret düzeyini korumakta zorlanacak, ya bütçe açı̆̆ına, ya da ücretlerin düşürülmesi nedeniyle sosyal hoşnutsuzluklara ve oy kaybına razı olacaktır ki her ikisi de arzu edilmeyen durumlardır. Keynesyen iktisat teorisinde de belirtildiği gibi; ücretler yukarı doğru esnek, aşağı doğru yapışkandır. Yani ücretle çalışan bireyler ve sendikalar ücretlerinin artmasından memnun olurken, düşürülmesine tepki gösterirler (Yıldırım, Karaman ve Taşdemir, 2009: 146). Bunun en net örneği Yunanistan'da yaşanmıştır. Hükümetler, daha fazla oy alabilmek için çalışanlara 14 ay ve oldukça yüksek maaşlar ödemeye başlamışlar (Gerçeğin Günlüğü, 2010), sonunda Yunanistan ekonomisi iflas etmiş, kamu kesimi toplam borç stokunun, gayrı safi yurtiçi hasılaya (GSYH) oranı, 2011 yılında \%172'ye ulaşmıştır (IMF, 2017). Bunun üzerine Yunan hükümeti, memur maaşlarından \%20, asgari ücretten \%22, emekli maaşlarından \%15 kesinti yapılmasına, 750 bin kamu çalışanının 150 bininin işten çıkarılmasına karar vermiştir Yaşanan gelişmeler üzerine ülkede yaygın sokak olayları ve protesto yürüyüşleri yaşanmıştır (Aljazeera, 2012).

Bir ülkede Hollanda Hastalığının ortaya çıkması için illa ki yeni bir doğal kaynak bulunması da şart değildir. Var olan bir doğal kaynağın dünya genelinde fiyatının aşırı derecede artması (Mironov ve Petronevich, 2015), ülkeye gelen yüksek miktardaki işçi dövizleri ya da portföy yatırımları da benzer etkilere yol açabilmektedir (Smith, 2014).

Doğal kaynak zengini her ülke Hollanda Hastalığına yakalanacaktır şeklinde bir genelleme yapmak yanlıştır. Hollanda Hastalığı konusunda ekonomistler arasında farklı görüşler bulunmaktadır. Gregory (1976), keşfedilen büyük miktardaki doğal kaynağın, vatandaşların harcanabilir gelir düzeylerini artırarak, mal ve hizmet taleplerini yükselteceğini ve enflasyona yol açacağını belirtirken, Sachs ve Warner (2001) yüksek doğal kaynak ihracatının Hollanda Hastalığına yol açarak, ekonomik büyümeyi olumsuz etkileyeceğini, Lederman ve Maloney (2008) ise yüksek doğal kaynak ihracatının ekonomiyi olumlu yönde etkileyeceğini iddia etmektedir. Sala-i-Martin ve Subramanian'a (2003) göre Nijerya'da petrol ihracat Hollanda hastalığına yol açmamıştır. Ueno (2010), yüksek miktardaki doğal kaynak ihracatının, ülkenin dış ticaret rekabet gücünü azalttğını ve 
diğer sanayi dallarını gerilettiğini ifade etmektedir. Broz ve Dubravcic'e (2011) göre yüksek miktardaki doğal kaynak ihracat, reel ücretlerin yükselmesine ve sanayinin gerilemesine neden olarak, ekonomik büyümeyi olumsuz etkilemektedir. Burada belirleyici olan husus, elde edilen doğal kaynak gelirlerinin nasıl değerlendirildiğidir. Politika yapıcıların, doğal kaynaklara bağı olarak ekonomide oluşacak canlanmayı ve riskleri başarılı bir şekilde yönetmesi durumunda, doğal kaynaklar ekonomik büyümeyi olumlu yönde etkileyecektir.

\section{Orta Asya Türk Cumhuriyetlerinde Makroekonomik Görünüm}

Orta Asya Türk Cumhuriyetleri genellikle enerji ve diğer doğal kaynaklar yönünden zengindir. 2015 yılı itibariyle Kazakistan 30, Azerbaycan 7, Türkmenistan ve Özbekistan 0.6 milyar varil ispatlanmış petrol rezervine sahiptir (BP, 2016). 2015 sonu itibariyle ispatlanmış doğal gaz rezervlerine bakıldığında ise Türkmenistan 17.5, Azerbaycan ve Özbekistan 1.1 ve Kazakistan 0.9 Trilyon $\mathrm{m}^{3}$ ile dünya doğal gaz rezervlerinin \%11.1'ini ellerinde bulundurmaktadırlar (BP, 2016). Ayrıca Kazakistan; kömür, demir ve uranyum yönünden zengin bir ülke olup, dünyanın en büyük uranyum üreticisi durumundadır. Kırgızistan'da altn, uranyum, civa, kömür ve antimon madenleri çıkarılırken, Tacikistan, zengin alüminyum yataklarına sahip olup, 2015 yılı ihracatının \%55.8'ini maden ihracatından elde etmiştir (World Bank, 2017a). Türkmenistan aynı zamanda pamuk yetiştiriciliğinde önemli bir yere sahip olup, ihracat gelirlerinin \%20'sini tarım ürünlerinden elde etmektedir (World Bank, 2017e). Bu ülkelerin ihracatında doğal kaynak (petrol, doğal gaz, kömür, mineral ve orman ürünleri) gelirlerinin payları Tablo 1'de yer almaktadır.

Tablo 1. Doğal Kaynak Gelirinin GSYH'ye Oranı (\%)

\begin{tabular}{ccccccc}
\hline & Azerbaycan & Kazakistan & Türkmenistan & Tacikistan & Özbekistan & Kırgızistan \\
\cline { 2 - 7 } $\mathbf{1 9 9 8}$ & 4.4 & 2.8 & 8.4 & 6.6 & 3.9 & 0.5 \\
\hline $\mathbf{2 0 0 0}$ & 35.3 & 24.6 & 68.2 & 2.5 & 12.1 & 1.1 \\
\hline $\mathbf{2 0 0 5}$ & 38.9 & 27.7 & 61.1 & 1.7 & 19.0 & 4.2 \\
\hline $\mathbf{2 0 0 6}$ & 44.6 & 26.9 & 63.2 & 1.8 & 28.4 & 4.7 \\
\hline $\mathbf{2 0 1 0}$ & 30.5 & 21.0 & 19.1 & 2.7 & 14.4 & 11.3 \\
\hline $\mathbf{2 0 1 1}$ & 35.1 & 23.7 & 32.2 & 3.1 & 19.8 & 12.4 \\
\hline $\mathbf{2 0 1 2}$ & 32.0 & 20.1 & 36.7 & 2.5 & 22.4 & 7.1 \\
\hline $\mathbf{2 0 1 3}$ & 26.5 & 16.6 & 29.5 & 2.0 & 17.1 & 9.1 \\
\hline $\mathbf{2 0 1 4}$ & 22.1 & 15.5 & 25.6 & 2.5 & 14.1 & 7.8 \\
\hline $\mathbf{2 0 1 5}$ & 13.3 & 9.2 & 18.9 & 2.0 & 9.4 & 7.7 \\
\hline
\end{tabular}

Kaynak: World Bank, (2017a).

Tablo 2. Doğal Kaynak Gelirinin Toplam Mal İhracatı İçindeki Yeri (\%)

\begin{tabular}{ccccccc}
\hline & Azerbaycan & Kazakistan & Türkmenistan & Tacikistan & Özbekistan & Kırgızistan \\
\cline { 2 - 7 } $\mathbf{1 9 9 8}$ & 32.3 & 11.6 & 37.2 & 14.5 & 16.7 & 1.6 \\
\hline $\mathbf{2 0 0 0}$ & 96.7 & 51.1 & 79.0 & 2.7 & 58.9 & 3.1 \\
\hline $\mathbf{2 0 0 5}$ & 67.4 & 56.8 & 80.1 & 4.4 & 57.2 & 15.4 \\
\hline $\mathbf{2 0 0 6}$ & 71.9 & 56.9 & 90.8 & 3.7 & 87.6 & 15.0 \\
\hline $\mathbf{2 0 1 0}$ & 60.9 & 51.9 & 66.3 & 12.7 & 48.4 & 30.8 \\
\hline $\mathbf{2 0 1 1}$ & 67.2 & 54.1 & 72.3 & 15.8 & 68.4 & 38.8 \\
\hline $\mathbf{2 0 1 2}$ & 67.4 & 48.4 & 78.1 & 13.8 & 93.4 & 24.9 \\
\hline $\mathbf{2 0 1 3}$ & 61.6 & 46.4 & 68.7 & 14.4 & 78.3 & 33.3 \\
\hline $\mathbf{2 0 1 4}$ & 58.7 & 43.2 & 63.6 & 23.4 & 68.0 & 31.1 \\
\hline $\mathbf{2 0 1 5}$ & 93.0 & 37.0 & 48.5 & 17.7 & 48.1 & 30.2 \\
\hline
\end{tabular}

Kaynak: World Bank, (2017a; 2017c ve 2017f) kullanılarak tarafımızdan doluşturulmuştur. 
Görüldüğü gibi doğal kaynak ihracat Orta Asya Türk Cumhuriyetlerinin milli gelirinde önemli bir yere sahiptir. Azerbaycan'ın 2006 yılındaki GSYH'sinin neredeyse yarısı (\%44.6) doğal kaynak ihracatından oluşurken bu oran Kazakistan'da 2005'te \%27.7, Türkmenistan'da 2000 yılında \%68.2, Tacikistan'da 1998'de \%6.6, Özbekistan'da 2006'da \%28.4 ve Kırgızistan'da 2011'de \%12.4 olmuştur. Bu ülkelerin doğal kaynak ihracatlarının toplam ihracat içindeki payları Tablo 2'de yer almaktadır.

Tablo 2'den de izlenebileceği gibi; Azerbaycan'ın 2000'deki ihracatının \%96.7'si, Kazakistan'ın 2006'daki ihracatının \%90.8'i, Tacikistan'ın 2011 yılındaki ihracatının \%15.8'i, Özbekistan'ın 2012'deki ihracatının \%93.4'ü ve Kırgızistan'ın 2011'deki ihracatının \%38.8'i doğal kaynaklardan oluşmaktadır. Bu oranlar oldukça yüksek olup, ülkelerin ihracatta ürün çeşitlemesine gitmelerinde yarar vardır.

Buraya kadar Orta Asya Türk Cumhuriyetlerinin genel olarak doğal kaynak ihracatçısı olduğu görüldü. Oysa ülkelere ihracatta asıl katma değer kazandıran ürünler, işlenmeden satılan doğal kaynaklar değil, yüksek teknolojili ürünlerdir. Yüksek teknolojili ürünler 2015 ihracatının Kazakistan'da \%41.2'sini, Kırgızistan'da \%11.9'unu, Azerbaycan'da ise \%2.5'ini oluşturmuştur (World Bank, (2017h). Tacikistan için 2000 yılına ait \%41.7 gibi oldukça yüksek bir oran görülmesine karşlık, bu serinin güncel değerlerine ulaşılamadığ ${ }^{1}$ için genel bir yorum yapılamamıştr. Özbekistan'ın yüksek teknolojili ürün ihracat verilerine ise ulaşılamamıştır. Kazakistan'da bu oranın yüksekliğinin arkasında, Kazakistan'ın SSCB'nin uzay mekiği firlatma rampasının yer aldığı Baykonur Uzay Üssü’nü sınırları içinde bulundurmasının ve burada sürdürülen ileri teknoloji araştırmalarının olduğu değerlendirilmektedir. Genel olarak bu ülkelerin yüksek teknolojili ürün üretimine ve ihracına önem vermelerinin gerektiği söylenebilir. Orta Asya Türk Cumhuriyetlerinin 2015 yılı genel makroekonomik büyüklükleri Tablo 3'te sunulmuştur.

Tablo 3. Orta Asya Türk Cumhuriyetlerinin Genel Makroekonomik Görünümü (2015)

\begin{tabular}{|c|c|c|c|c|c|c|}
\hline \multirow[b]{2}{*}{ Nüfus (Milyon) } & \multirow{2}{*}{$\begin{array}{c}\text { Azerbaycan } \\
9.7\end{array}$} & \multicolumn{5}{|c|}{ Kazakistan Türkmenistan Tacikistan Özbekistan Kırgızistan } \\
\hline & & 17.5 & 5.4 & 8.5 & 31.3 & 6.0 \\
\hline GSYH (Milyar \$) & 53.0 & 184.4 & 35.9 & 7.9 & 66.7 & 6.6 \\
\hline Büyüme (\%) & 1.1 & 1.2 & 6.5 & 6.0 & 8.0 & 3.5 \\
\hline Kişi Başına Gelir (\$) & 5496 & 10510 & 6672 & 926 & 2132 & 1103 \\
\hline îhracat (Milyar \$) & 14.5 & 45.7 & 14.0 & 0.9 & 13.0 & 1.7 \\
\hline ithalat (Milyar \$) & 9.4 & 30.2 & 7.8 & 3.4 & 14.0 & 4.1 \\
\hline $\begin{array}{l}\text { İhracatın İthalatı } \\
\text { Karşılama Oranı (\%) }\end{array}$ & 154.3 & 151.5 & 179.5 & 26.5 & 92.9 & 41.2 \\
\hline İşsizlik Oranı (\%) & 5.2 & 4.1 & 10.5 & 10.9 & 10.6 & 8.1 \\
\hline Enflasyon Oranı (\%) & 4.1 & 6.4 & 5.5 & 5.7 & 8.5 & 6.5 \\
\hline
\end{tabular}

Kaynak: World Bank, (2017i; 2017c; 2017j; 2017k; 2017f; 2017m; 2017n; 2017p) ve Asian Development Bank (2017).

Tablo 3 incelendiğinde nüfus olarak en büyük ve ekonomik büyümesi en yüksek olan ülkenin Özbekistan olduğu, GSYH, kişi başına düşen milli gelir, ihracat ve ithalatın Kazakistan'da yüksek olduğu, ihracatın ithalatı karşılama oranının Tacikistan ve Kırgızistan haricinde iyi olduğu, işsizliğin Türkmenistan, Tacikistan ve Özbekistan'da görece yüksek bulunduğu görülmektedir. Bu ülkelerde enflasyonun önemli bir sorun teşkil etmediği de dikkati çekmektedir.

\section{Literatür İncelemesi}

Önce diğer ülkeler, sonra Orta Asya Türk Cumhuriyetleri için yapılan çalışmaların seçilmiş bir özeti, tarih sırasına göre buraya alınmıştır.

Rodriguez (2006), Suudi Arabistan'ın dünyanın en büyük petrol üreticilerinden biri olduğunu, bunun bir sonucu olarak da ülke ekonomisinin petrole yüksek düzeyde bağımlı bulunduğunu, ancak petrol 
gelirlerinin 1970'lerin sonlarından itibaren bu ülkede işgücü piyasasını aşııı ısındırdığını, yabancı işgücüne olan talebi artırdığını, enflasyonu yükselttiğini ve ülkede ekonomik istikrarı bozmaya başladığını, yani Hollanda Hastalığı belirtilerinin görüldüğünü ifade etmiştir. Oomes ve Kalcheva (2007), ihracatının \%60'ı, GSYH'sinin \%20-25'i petrol, petrol ürünleri ve doğal gazdan gelen Rusya'da Hollanda Hastalığının belirtilerini 1995:M012005:M12 dönemi için Johansen eşbütünleşme yöntemiyle araştırdığı çalışmasında reel efektif döviz kurunu; petrol fiyatlarındaki \%1'lik artışın \%0.58, kamu harcamalarındaki artşın \%1.32, verimlilik farklarındaki artş̧ın \%1.08 arttırdığını, yolsuzluk endeksindeki \%1'lik artş̧ın ise \%0.53 oranında azalttı̆ını belirlemiştir. Yürük (2008), Hollanda Hastalı̆̆ı riskini Rusya için Cochrane-Orcutt yöntemiyle araştırdığı çalışmada, petrol ve doğal gaz fiyatlarındaki artışların reel efektif döviz kurunu yükselttiğini, reel efektif döviz kurunun işsizlik ile pozitif, ihracat ile negatif korelasyonlu olduğunu belirleyerek, Rusya ekonomisinde Hollanda Hastalığı belirtilerinin olduğunu ifade etmiştir. Hasanov (2010), petrol fiyatlarının, reel efektif döviz kuru üzerindeki etkisini Azerbaycan'ın 2000:Q1-2007:Q4 dönemi verileriyle ARDL yöntemiyle incelediği çalışmada; petrol fiyatlarındaki \%1'lik artş̧ı reel efektif döviz kurunu \%0.7 artırdığını belirtmiştir. İsmail (2010), Hollanda Hastalı̆ıını 1977-2004 dönemi verileriyle petrol ihraç eden 90 ülke için Kalman filtresi yöntemiyle incelediği çalışmada; petrol fiyatlarındaki artışların, imalat sanayi çıktısını, Hollanda Hastalığı hipotezinde olduğu gibi önemli ölçüde azalttı̆ını, bu etkinin sermaye açısından dışa açık ülkelerde daha net görüldüğünü belirlemiştir. Arı ve Özcan (2012), Hollanda Hastalığı olgusunu işçi dövizleri noktasından, 24 tane gelişmekte olan ülke için 1988-2009 dönemi verilerini kullanarak panel veri analiz yöntemiyle incelediği çalışmada; işçi dövizi gelirlerindeki \%1'lik artısın, bu ülkelerde reel kuru \%0.033 oranında artırdığını, dolayısıyla bu ülkelerde Hollanda Hastalığı olgusunun geçerli olduğunu belirlemiştir. Akçacı ve Karaata (2014), uluslararası fonların Türkiye'de Hollanda Hastalığına neden olup olmadığını, 2006:M01-2013:M12 dönemi için Toda-Yamamoto (1995) ve Hacker-Hatemi-J (2006) nedensellik testleriyle incelemiştir. Portföy yatırımları ile sanayi üretim endeksi ve ihracat arasında nedensellik ilişkisi tespit edilemediği için portföy yatıımlarının, Hollanda Hastalığına yol açmadığına karar vermiştir. Bacak (2014), Hollanda Hastalığı'nı sanayisizleşme olgusu etrafinda Türkiye ekonomisi için incelemiş ve Türkiye ekonomisinin, 2006-2012 arasında sürekli cari işlemler açığı verdiğini, cari açığın finansmanında 2008 yılından bu yana Amerikan Merkez Bankası FED'in izlemekte olduğu parasal genişlemeci para politikasına dayalı ucuz dış kaynaklardan yararlandığını, ancak bu durumun sürdürülebilir olmadığını belirtmiştir. 2006-2012 yılları arasında Türkiye'ye gelen doğrudan yabancı yatırımcıların (DYY) \% 66.5'inin ticarete konu olmayan sektörlere (inşaat, enerji, finans, toptan ve perakende, ulaşttrma, haberleşme ve depo hizmetleri) yönelik olduğunu, imalat sanayinin DYY'den aldığı payın sadece \% 20.6 olduğunu beyan eden yazar, bu durumun ülkede sanayisizleşmeye neden olduğunu belirtmiştir. Bunun ana nedeninin ise Türkiye'de, özellikle nitelikli üretim gerçekleştirecek, imalat sanayi alt sektörlerinin cazibesini kaybetmesi olduğunu vurgulamıştr. Yazar ayrıca; 1970 'li yıllarda emtia fiyatlarının yükselmesi ile doğal kaynak zengini haline gelen ülkelerin kaynaklarını büyük lüks yatırım projelerine aktarması ile günümüz ucuz borçlanma döneminde girişimcilerin sahip oldukları ekonomik kaynakları kısa vadeli rant getirecek alanlara kanalize etmesi arasında pek bir fark olmadığını da ifade etmiştir. Şahin ve Kutluay Şahin (2015), Rusya'da Hollanda Hastalığı riskini araştırdığı çalışmada, Rusya'nın 1991 yılında bu hastalığa yakalandığını, bunun nedeninin yüksek miktardaki petrol, doğal gaz ve kömür ihracatı olduğunu belirtmiştir. Rusya'da enerji alanındaki yüksek karlılığın firmaları bu sektöre çektiğini fakat bu arada diğer alanlarda bir sanayisizleşme probleminin ortaya çıktğını ifade etmiştir. Berikan ve Hüseyinli (2017), petrol fiyatlarındaki düşüşün, 2013 yılı itibarıly petrol ve doğal gaz ihracatı toplam ihracat gelirinin \%68'ini oluşturan Rusya ekonomisini derinden etkilediğini, Rusya'nın oluşan finansal krizle mücadele için 6 trilyon dolar maliyete katlandığını ifade etmiştir. Akça ve Bal (2017), yurtdışı işçi gelirlerinin makroekonomik etkilerini Hollanda Hastalığı perspektifinde, en fazla yurtdışı iş̧i gelirleri elde eden 9 ülkeye ait 1990-2014 dönemi verilerini kullanarak, iki yönlü rassal etkiler modeli yardımıyla gerçekleştirdiği panel veri analizinde, yurtdışında çalışan işçiler tarafindan ana ülkelerine gönderilen paraların, bu ülkelerde nominal döviz kurunu düşürerek reel kurun artmasına yol açtı̆ını ve bu nedenle söz konusu ülkelerde Hollanda Hastalığı riskinin geçerli olduğunu belirlemiş, bu nedenle bu ülkelerde başta Merkez Bankaları olmak üzere ilgili kurumlarca belirlenen makroekonomik politikaların, Hollanda Hastalı̆ıı'nı önleyici yönde uygulanması gerektiğine işaret etmiştir.

Hoen (2010), Kırgızistan, Kazakistan, Tacikistan, Türkmenistan ve Özbekistan'da enerji yoğun ekonomik yapının sürdürülebilir ekonomik yapıya olan etkilerini ve Hollanda Hastalığı riskini tartştı̆ı 
çalışmasında, bu ülkelerde doğal kaynakların ekonomik büyümeye ivme kazandırabileceğini ancak sürdürülebilir bir ekonomik büyümenin elde edilmesinin ve Hollanda Hastalığı risklerinden kaçınmanın güçlüklerinin devam ettiği belirtmiştir. Bulut ve Suleymanov (2012), Azerbaycan'ın Hollanda Hastalığı problemini önleme stratejilerinde Türkiye ile yapılan ekonomik ilişkilerin önemini tartıştığı çalışmada; Azerbaycan'ın zengin petrol ve doğal gaz kaynakları nedeniyle ekonomik olarak hızla büyüdüğünü, ancak bu büyüme esnasında Hollanda Hastalı̆̆ yaşama riskinin var olduğunu belirtmiştir. Azerbaycan ile Türkiye arasında yapılan; Aliağa PETKIM tesislerinin Azeri SOCAR firmasına satılması ve TANAP doğalgaz boru hattı projesinin hayata geçirilmesi gibi ekonomik işbirliği anlaşmalarının, bu ülkenin ekonomik temellerinin güçlenmesine katkı sağlayacağı vurgulanmıştır. Bature (2013), Kazakistan'ın ihracatında ve GSYH'si içinde petrol gelirlerinin payının hızla arttı̆ını ve bunun ileride bu ülkeyi Hollanda Hastalığı durumuyla karşı karşıya getirebileceğini ifade etmiştir. Yıldırım Mızrak ve Gurbanov (2013), Azerbaycan'da enerji kaynakları sektöründe yaşanan Hollanda Hastalı̆ııın makroekonomik etkilerini, Norveç ile karşılaştırmalı olarak analiz ettiği çalışmada, petrol gelirleri ile bütçe harcamaları arasındaki ilişkiye odaklanmıştır. 2013 yılı itibariyle bütçe harcamalarının \%57'sinin petrol fonundan transfer edildiğini ve bunun sağlıklı bir yol olmadığını belirtmiştir. Mercan ve Göçer (2014), Azerbaycan, Kazakistan, Kırgızistan ve Tacikistan'da Hollanda Hastalığı riskinin varlığını 1990-2011 dönemi için panel veri analizi yöntemiyle test ettiği çalışmada, bu ülkelerde petrol fiyatlarındaki artı̧ların, reel döviz kurunu negatif yönde etkilediği ve söz konusu hipotezin geçerli olmadığı sonucuna ulaşmıştir. Akça, Bal ve Demiral (2015), MENA ve Hazar ülkelerinde doğal kaynak zenginliği ve ekonomik büyüme ilişkisinde yönetişim göstergelerinin aracılık etkisini 1996-2013 dönemi için panel veri yöntemiyle incelemiştir. Analiz sonucunda; doğal doğal kaynak zenginliğinin ekonomik büyümeyi artırma eğiliminde olduğunu, ama yönetişim göstergelerini anlamlı biçimde kötüleştirdiğini belirlemiştir. Dünya Bankası baş ekonomistlerinin 2015 yılında yaptıkları çalışmada petrol fiyatlarındaki artışların, ülkelerin reel efektif döviz kurlarına olan etkileri regresyon analizleriyle incelenmiş, petrol fiyatlarındaki \%1'lik artışın Kırgızistan'da reel efektif döviz kurunu \%0.45 oranında artırdığı ve Hollanda Hastalığı durumunun geçerli olduğu belirtilmiştir.

Literatürde yer alan çalışmalara genel olarak bakıldığında; petrol fiyatları ile petrol ihracatçısı ülkelerin reel döviz kurları ve ekonomik istikrarları arasında yakın bir iliş̧inin var olduğu görülmektedir. Dikkat çeken bir diğer nokta ise Orta Asya Türk Cumhuriyetlerini inceleyen ampirik çalışmaların oldukça sınırlı olduğudur. Bu yönüyle, bu çalışmanın literatüre önemli bir katkı sağlayacağı düşünülmektedir.

\section{Analiz}

\subsection{Veri Seti}

Bu çalışmada Orta Asya Türk Cumhuriyetlerinde Hollanda Hastalığının varlığını ve bunun, ülkelerin ihracat performanslarına etkilerini araşttrmak üzere; Azerbaycan, Kazakistan, Türkmenistan, Tacikistan, Özbekistan ve Kırgızistan'ın 1998-2015 dönemi aşağıdaki verileri kullanıımıştır:

Reel Efektif Döviz Kuru (LnREER): Ülkelerin dış ticaret rekabet gücünün göstergesi olarak görülen reel efektif döviz kuru serisi Darvas (2017) ${ }^{2}$ den edinilip, logaritması alınmıştır.

Brent Petrolü Varil Fiyatı (LnPoil): Artan petrol fiyatlarının ülkelerin reel efektif döviz kurlarını ve diğer değişkenlerini etkileyerek Hollanda Hastalığına yol açıp açmadığını belirleyebilmek için kullanılan petrol fiyatları, (BP, 2016)'dan alınmış ve logaritmik olarak kullanılmıştır.

Doğal Kaynak Geliri (LnDKG): Ülkelerin doğal kaynak gelirlerindeki artşların etkilerinin tespiti için kullanılan doğal kaynak geliri serisi; World Bank (2017a)'dan GSYH'nin \%'si olarak alınıp, World Bank (2017c)'den alınan GSYH değerleriyle çarpılıp, 100'e bölünerek elde edilmiş ve logaritması alınmıştır.

Işsizlik Oranı (UN): Hollanda Hastalığının reel efektif döviz kuruyla ölçülemediği durumlarda ek bağımlı değişken olarak analizlerde kullanılan işsizlik oranları serisi; Asian Development Bank (2017), IMF (2016) ve World Bank (2017n)'den derlenmiş olup, işsizlerin, toplam işgücü içindeki \%'sini ifade etmektedir. 
Enflasyon (P): Hollanda Hastalığının reel efektif döviz kuruyla ölçülemediği durumlarda ek bağımlı değişken olarak analizlerde yer verilen enflasyon oranı serisi; Asian Development Bank (2017), Data Market (2017), Quandl (2017a), Quandl (2017b) ve World Bank (2017p)'den derlenmiş olup, yıllık \% değişimleri göstermektedir.

ihracat (X): Artan doğal kaynak geliriyle birlikte değişen reel efektif döviz kurunun ülkelerin ihracat performanslarına etkilerini belirleyebilmek için World Bank (2017f)'den alınmış, logaritmik olarak kullanılmıştr.

Dış Ticaret Dengesi $(X / M)$ : Artan doğal kaynak geliriyle birlikte değişen reel efektif döviz kurunun ülkelerin dış ticaret dengesine olan etkilerini belirleyebilmek için World Bank (2017f) ve (2017m)'den alınmıştır. Ihracat, ithalata bölünüp, 100 ile çarpılarak elde edilmiştir.

\subsection{Modeller}

Çalışmada Orta Asya Türk Cumhuriyetlerinde Hollanda Hastalı̆̆ının varlığını ve bunun, ülkelerin ihracat performanslarına etkilerini araştırmak üzere, Oomes ve Kalcheva (2007); Yürük (2008); Hasanov (2010); Mercan ve Göçer (2014) izlenerek aşağıdaki modeller oluşturulmuştur³:

\begin{tabular}{|c|c|}
\hline Model 1 & $\operatorname{LnREER}_{i t}=\beta_{0}+\beta_{1}$ LnPoil $_{i t}+u_{i t}$ \\
\hline Model 2 & $\operatorname{LnREER}_{i t}=\alpha_{0}+\alpha_{1} \operatorname{LnDK} G_{i t}+v_{i t}$ \\
\hline Model 3 & $U N_{t}=\psi_{0}+\psi_{1} L n D K G_{t}+e_{i t}$ \\
\hline Model 4 & $P_{i t}=\gamma_{0}+\gamma_{1} L n D K G_{i t}+\vartheta_{i t}$ \\
\hline Model 5 & $L n X_{i t}=\theta_{0}+\theta_{1} L_{n P o i l}{ }_{i t}+\varepsilon_{i t}$ \\
\hline Model 6 & $\operatorname{Ln} X_{i t}=\rho_{0}+\rho_{1} \operatorname{LnREER_{it}}+\epsilon_{i t}$ \\
\hline Model 7 & 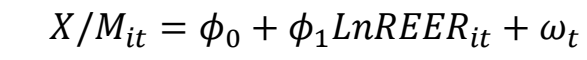 \\
\hline
\end{tabular}

Bu modellerle ilgili literatürdeki yaygın yaklaşım; $\beta_{1}$ pozitif olduğunda ya da petrol fiyatlarından reel efektif döviz kuruna doğru bir nedensellik ilişkisi tespit edildiğinde Hollanda Hastalığının var olduğuna karar verilmesidir (Oomes ve Kalcheva, 2007; Yürük, 2008; Hasanov 2010; Mercan ve Göçer, 2014) . Benzer bir durum tarafimızdan Model (2), (3) ve (4) için de uyarlanmıştır. Model (5) petrol fiyatlarının ülkelerin ihracat performansı üzerindeki etkisini doğrudan ölçerken, Model (6) ve (7) dolaylı olarak ölçmektedir.

Orta Asya Türk Cumhuriyetleri her dönemde serbest kur politikası uygulamamıştır. Örneğin; Azerbaycan 1994-2014 döneminde sabit kur politikası uygulamış, 2014'ten sonra kontrollü dalgalı kur politikasını benimsemiştir. 2015'te Azerbaycan, kur baskısına dayanamayarak ulusal parasını Şubat 2015'te \%25.7, Aralık 2015'te \%32.2, 2016 yılında \%12.2 devalüe ederek toplamda \%57 değer kaybetmesini sağlamıştir (Hasanov, 2017). Böylece reel efektif döviz kurunu düşürmeyi ve dış ticarette rekabet gücünü artırmayı hedeflemiştir. Orta Asya Türk Cumhuriyetlerinde piyasa koşullarına göre serbest dalgalanan bir kur sistemi olmadığı için Hollanda Hastalığı riskini sadece reel efektif döviz kuruyla ölçmek mümkün olmayacaktır. Bu nedenle tarafimızdan petrol fiyatları ve doğal kaynak gelirleri de çalışmada açıklayıcı değiş̧kenler olarak modellere dâhil edilmiştir. Bu da literatüre ek bir katkıdır.

\subsection{Yöntem}

Çalışmaya konu ülkeler birbiriyle yakın etkileşim içinde oldukları için aralarında yatay kesit bağımlıı̆ı olabilecektir. Bu nedenle analize, ülkeler arasında yatay kesit bağımlılığının varlığının test edilmesiyle başlanmıştır. Serilerin durağanlığı; çoklu yapısal kırılmalı PANKPSS panel birim kök testiyle incelenmiştir. Regresyon analizleri havuzlanmış EKK, sabit etkiler modeli ve rassal etkiler modeli yardımıyla gerçekleştirilmiş, seriler arasındaki nedensellik ilişkileri Dumitrescu ve Hurlin (2012) testiyle belirlenmiştir. 


\subsection{Yata Kesit Bağımlılığı Testi}

Panel veri analizlerinde, özellikle birbirleriyle etkileşim içinde olan ülkelerle çalışılırken, yatay kesit bağımlılığının varlığının test edilmesi büyük önem arz etmektedir. Yatay kesit bağımlılı̆̆ı testi; bir ülkeye gelen şokun, diğer ülkeleri de etkileyip etkilemediğini belirmeye imkân sağlamaktadır. Eğer ülkeler arasında yatay kesit bağımlılığı yoksa birinci, varsa ikinci nesil panel veri analizi yöntemlerinin kullanılması gerekmektedir. Yatay kesit bağımlılı̆ının test edilmesine yönelik olarak ilk geliştirilen yöntem Breusch ve Pagan (1980) $L M$ testi olup, bunu Pesaran (2004) $L M_{s}$ testi, Pesaran (2004) CD testi ve Baltagi, Feng ve Kao (2012) sapması düzeltilmiş $L M_{B C}$ testi takip etmiştir. Testin boş hipotezi; 'yatay kesit bağımlılığı yoktur' şeklindedir. Çalışmada bu dört test de yapılmış ve sonuçlar Tablo 4 'te sunulmuştur.

Tablo 4. Yatay Kesit Bağımlılığı Test Sonuçları

\begin{tabular}{|c|c|c|c|c|}
\hline & $L M$ & $L M_{s}$ & $C D$ & $L M_{B C}$ \\
\hline LnREER & $102.62^{* * *}(0.00)$ & $14.90 * * *(0.00)$ & $1.25(0.20)$ & $14.72^{* * *}(0.00)$ \\
\hline LnPoil & $270.00 * * *(0.00)$ & $45.46 * * *(0.00)$ & $16.43 * * *(0.00)$ & $45.28 * * *(0.00)$ \\
\hline$D K G \_X$ & $62.90 * * *(0.00)$ & $7.65^{* * *}(0.00)$ & $2.98 * * *(0.002)$ & $7.47 * * *(0.00)$ \\
\hline LnDKG & $203.83 * * *(0.00)$ & $33.38 * * *(0.00)$ & $33.20 * * *(0.00)$ & $14.11 * * *(0.00)$ \\
\hline UN & $74.85^{* * *}(0.00)$ & $9.83 * * *(0.00)$ & $7.43 * * *(0.00)$ & $9.65 * * *(0.00)$ \\
\hline$P$ & $53.65^{* * *}(0.00)$ & $5.96 * * *(0.00)$ & $5.78 * * *(0.00)$ & $4.80 * * *(0.00)$ \\
\hline $\operatorname{Ln} X$ & $215.73^{* * *}(0.00)$ & $35.55 * * *(0.00)$ & $\left.14.63^{* * *} 0.00\right)$ & $35.37 * * *(0.00)$ \\
\hline LnM & $240.92 * * *(0.00)$ & $40.15^{* * *}(0.00)$ & $15.51^{* * *}(0.00)$ & $39.97 * * *(0.00)$ \\
\hline$X / M$ & $57.70 * * *(0.00)$ & $6.70 * * *(0.00)$ & $-0.19(0.84)$ & $6.52 * * *(0.00)$ \\
\hline
\end{tabular}

Not: Parantez içindekiler olasılık değerleridir. ${ }^{* * * *}$; ilgili seride $\% 1$ anlamlılık düzeyinde ülkeler arasında yatay kesit bağımlıı̆ı̆ıın varlığını ifade etmektedir.

Tablo 4'teki sonuçlar göre bu ülkeler arasında yatay kesit bağımlılı̆̆ vardır. Bu nedenle çalışmada ikinci nesil panel veri analiz yöntemleri kullanılmalıdır.

Tablo 5. Birim Kök Testi Sonuçları

\begin{tabular}{|c|c|c|c|c|c|c|c|}
\hline & Azerbaycan & Kazakistan & Türkmenistan & Tacikistan & Özbekistan & Kırgızistan & Panel \\
\hline LnREER & $\begin{array}{c}0.042 * * * \\
(0.121) \\
{[2004 ; 2009]}\end{array}$ & $\begin{array}{c}0.044 * * * \\
(0.116) \\
{[2000 ; 2007]}\end{array}$ & $\begin{array}{c}0.080 * * * \\
(0.134) \\
{[2000]}\end{array}$ & $\begin{array}{c}0.065 * * * \\
(0.147) \\
{[2002 ; 2007]}\end{array}$ & $\begin{array}{c}0.065^{* * *} \\
(0.144) \\
{[2003]}\end{array}$ & $\begin{array}{c}0.090 * * * \\
(0.176) \\
{[-]}\end{array}$ & $\begin{array}{c}2.93 * * * \\
(9.397)\end{array}$ \\
\hline LnPoil & $\begin{array}{c}0.076 * * * \\
(0.161) \\
{[2012]} \\
\end{array}$ & $\begin{array}{c}0.076 * * * \\
(0.161) \\
{[2012]} \\
\end{array}$ & $\begin{array}{c}0.076 * * * \\
(0.161) \\
{[2012]} \\
\end{array}$ & $\begin{array}{c}0.076 * * * \\
(0.161) \\
{[2012]} \\
\end{array}$ & $\begin{array}{c}0.076 * * * \\
(0.161) \\
{[2012]} \\
\end{array}$ & $\begin{array}{c}0.076 * * * \\
(0.161) \\
{[2012]} \\
\end{array}$ & $\begin{array}{c}2.391 * * * \\
(9.164)\end{array}$ \\
\hline LnDKG & $\begin{array}{c}0.061^{* * *} \\
(0.105) \\
{[2000 ; 2011]}\end{array}$ & $\begin{array}{c}0.054 * * * \\
(0.153) \\
{[2007]} \\
\end{array}$ & $\begin{array}{c}0.068 * * * \\
(0.168) \\
{[2000]} \\
\end{array}$ & $\begin{array}{c}0.038 * * * \\
(0.152) \\
{[2000 ; 2007]}\end{array}$ & $\begin{array}{c}0.057 * * * \\
(0.157) \\
{[2011]} \\
\end{array}$ & $\begin{array}{c}0.088 * * * \\
(0.153) \\
{[2011]} \\
\end{array}$ & $\begin{array}{c}2.718^{* * *} \\
(8.108)\end{array}$ \\
\hline UN & $\begin{array}{c}0.112 * * * \\
(0.178) \\
{[2001]} \\
\end{array}$ & $\begin{array}{c}0.129 * * * \\
(0.185) \\
{[2000]} \\
\end{array}$ & $\begin{array}{c}0.084 * * * \\
(0.200) \\
{[2000]} \\
\end{array}$ & $\begin{array}{c}0.079 * * * \\
(0.186) \\
{[2001]}\end{array}$ & $\begin{array}{c}0.077^{* * *} \\
(0.203) \\
{[2009]} \\
\end{array}$ & $\begin{array}{c}0.054^{* * *} \\
(181) \\
{[2001 ; 2004]}\end{array}$ & $\begin{array}{c}4.752 * * * \\
(7.956)\end{array}$ \\
\hline$P$ & $\begin{array}{c}0.102 * * * \\
(0.177) \\
{[2008]}\end{array}$ & $\begin{array}{c}0.088 * * * \\
(0.172) \\
{[-]}\end{array}$ & $\begin{array}{c}0.074 * * * \\
(0.169) \\
{[-]}\end{array}$ & $\begin{array}{c}0.051 * * * \\
(0.202) \\
{[2001]}\end{array}$ & $\begin{array}{c}0.096 * * * \\
(0.150) \\
{[2002]}\end{array}$ & $\begin{array}{c}0.091 * * * \\
(0.172) \\
{[-]}\end{array}$ & $\begin{array}{c}2.253^{* * *} \\
(6.472)\end{array}$ \\
\hline $\operatorname{Ln} X$ & $\begin{array}{c}0.061 * * * \\
(0.165) \\
{[2006]}\end{array}$ & $\begin{array}{c}0.090 * * * \\
(0.139) \\
{[2008 ; 2012]}\end{array}$ & $\begin{array}{c}0.062 * * * \\
(0.175) \\
{[2008]}\end{array}$ & $\begin{array}{c}0.047 * * * \\
(0.160) \\
{[2005]}\end{array}$ & $\begin{array}{c}0.088 * * * \\
(0.089) \\
{[2002 ; 2007]}\end{array}$ & $\begin{array}{c}0.092 * * * \\
(0.161) \\
{[2006]}\end{array}$ & $\begin{array}{c}6.952 * * * \\
(12.514)\end{array}$ \\
\hline$X / M$ & $\begin{array}{c}0.063 * * * \\
(0.159) \\
{[2006]}\end{array}$ & $\begin{array}{c}0.069 * * * \\
(0.188) \\
{[-]}\end{array}$ & $\begin{array}{c}0.054 * * * \\
(0.189) \\
{[2005 ; 2008]}\end{array}$ & $\begin{array}{c}0.095^{* * *} \\
(0.191) \\
{[2000]}\end{array}$ & $\begin{array}{c}0.041 * * * \\
(0.221) \\
{[2002 ; 2011]}\end{array}$ & $\begin{array}{c}0.042^{* * *} \\
(0.216) \\
{[2001 ; 2008]}\end{array}$ & $\begin{array}{c}2.542 * * * \\
(9.194)\end{array}$ \\
\hline
\end{tabular}

Not: Parantez içindekiler; kritik değerlerdir. Köşeli parantez içindekiler; test tarafından belirlenen yapısal kırılma tarihleridir. ${ }^{* * *}$; ilgili serinin $\% 1$ anlamlılık düzeyinde durağan olduğunu ifade etmektedir. 


\subsection{Birim Kök Testleri}

Serilerin durağanlığı, yatay kesit bağımlılığını dikkate alan, serilerde çoklu yapısal kırılmaya izin veren ve yapısal kırılma tarihlerini içsel olarak belirleyebilen Carrion-i-Silvestre vd. (2005) tarafindan geliştirilen PANKPSS testiyle sınanmıştır. Testin boş hipotezi; 'yapısal kırılmalar altında seri durağandır' şeklindedir. Test sonuçları Tablo 5'te sunulmuştur.

Tablo 5'ten de görüldüğü gibi serilerin tamamı düzeyde durağandır. Test tarafindan belirlenen yapısal kırılma tarihlerine bakıldığında 2007, 2008 ve 2009 tarihleri; 2008 küresel finans krizinin izlerini yansıtmaktadır. Doğal kaynak gelirleriyle ilgili serilerde 2011 yılında görülen yapısal kırılmanın nedeni; 2010 'da 78 dolar olan ham petrol varil fiyatının 2011'de 106 dolara firlamış olmasıdır.

Seriler düzeyde durağan bulunduğu için çalışmada eşbütünleşme testi yapılmasına gerek kalmamış, doğrudan modellerin tahmini aşamasına geçilmiştir. Seriler durağan olduğu için yapılacak tahminlerde sahte regresyon problemiyle karşılaşılmayacaktır.

\subsection{Regresyon Analizi}

Durağan serilerle yapılacak regresyon analizleri; havuzlanmış en küçük kareler yöntemi, sabit etkiler yöntemi ya da rassal etkiler yöntemlerinden biriyle gerçekleştirilebilmektedir. Bu çalışmada muhtemel bütün durumlar göz önünde bulundurularak, tahmin sonuçlarının tamamı rapor edilmiştir. 2008 küresel ekonomik krizi kukla değişkenle $\left(K_{2008}\right)$ modellere dâhil edilmiş, sonuçlar Tablo 6 'da sunulmuştur.

Tablo 6. Regresyon Analizi Sonuçları

\begin{tabular}{|c|c|c|c|c|c|c|c|c|}
\hline & \multicolumn{3}{|c|}{ Havuzlanmış EKK } & \multicolumn{2}{|c|}{ Sabit Etkiler $\neq$} & \multicolumn{3}{|c|}{ Rassal Etkiler } \\
\hline & $\begin{array}{l}\text { Sabit } \\
\text { Terim }\end{array}$ & $\begin{array}{l}\text { Bağımsız } \\
\text { Değişken }\end{array}$ & $K_{2008}$ & $\begin{array}{l}\text { Sabit } \\
\text { Terim }\end{array}$ & $\begin{array}{l}\text { Bağımsız } \\
\text { Değişken }\end{array}$ & $\begin{array}{l}\text { Sabit } \\
\text { Terim }\end{array}$ & $\begin{array}{l}\text { Bağımsız } \\
\text { Değişken }\end{array}$ & $K_{2008}$ \\
\hline Model 1 & $\begin{array}{l}4.87 * * * \\
{[29.31]}\end{array}$ & $\begin{array}{l}-0.05^{*} \\
{[-1.31]}\end{array}$ & $\begin{array}{l}0.034 \\
{[0.27]}\end{array}$ & Q & Q & $\begin{array}{c}4.87 \\
{[30.42]}\end{array}$ & $\begin{array}{l}-0.05^{*} \\
{[-1.43]}\end{array}$ & $\begin{array}{c}0.03 \\
{[0.30]}\end{array}$ \\
\hline Model 2 & $\begin{array}{l}4.56 * * * \\
{[109.65]}\end{array}$ & $\begin{array}{c}0.0037 * * \\
{[1.95]}\end{array}$ & $\begin{array}{c}0.005 \\
{[0.086]}\end{array}$ & $\begin{array}{c}0.22 \\
{[0.20]}\end{array}$ & $\begin{array}{c}0.21 * * * \\
{[4.12]}\end{array}$ & $\begin{array}{c}4.56 * * * \\
{[8.28]}\end{array}$ & $\begin{array}{l}0.004 \\
{[0.18]}\end{array}$ & $\begin{array}{l}-0.009 \\
{[-0.13]}\end{array}$ \\
\hline Model 3 & $\begin{array}{c}18.45^{* * *} \\
{[9.60]}\end{array}$ & $\begin{array}{c}-0.42 * * * \\
{[-4.66]}\end{array}$ & $\begin{array}{c}-0.08 \\
{[-0.09]}\end{array}$ & $\begin{array}{c}14.73^{* * *} \\
{[2.88]}\end{array}$ & $\begin{array}{c}-0.24 \\
{[-1.02]}\end{array}$ & $\begin{array}{c}22.6 * * * \\
{[8.89]}\end{array}$ & $\begin{array}{c}-0.63 * * * \\
{[-5.26]}\end{array}$ & $\begin{array}{c}0.13 \\
{[0.22]}\end{array}$ \\
\hline Model 4 & $\begin{array}{c}35.6^{* * *} \\
{[2.99]}\end{array}$ & $\begin{array}{c}-1.23 * * * \\
{[-3.65]}\end{array}$ & $\begin{array}{c}9.99 * * * \\
{[2.99]}\end{array}$ & $\begin{array}{c}-97.81^{* * *} \\
{[-3.44]}\end{array}$ & $\begin{array}{c}5.11^{* *} \\
* \\
{[3.80]}\end{array}$ & $\begin{array}{c}38.34 * \\
{[1.50]}\end{array}$ & $\begin{array}{l}-1.36 \\
{[-1.16]}\end{array}$ & $\begin{array}{c}10.12 * * * \\
{[3.99]}\end{array}$ \\
\hline Model 5 & $\begin{array}{l}17.8^{* * *} \\
{[23.66]}\end{array}$ & $\begin{array}{c}1.12 * * * \\
{[5.88]}\end{array}$ & $\begin{array}{c}-0.0002 \\
{[-0.003]}\end{array}$ & ه & Ф & $\begin{array}{c}17.80 * * * \\
{[30.45]}\end{array}$ & $\begin{array}{l}1.12^{* * *} \\
{[17.19]}\end{array}$ & $\begin{array}{l}-0.002 \\
{[-0.01]}\end{array}$ \\
\hline Model 6 & $\begin{array}{c}22.67 * * * \\
{[47.60]}\end{array}$ & $\begin{array}{l}-0.089 \\
{[-0.90]}\end{array}$ & $\begin{array}{c}0.7^{* * *} \\
{[4.02]}\end{array}$ & $\begin{array}{c}17.89 * * * \\
{[7.76]}\end{array}$ & $\begin{array}{c}0.92 * * \\
{[1.87]}\end{array}$ & $\begin{array}{c}17.92^{* *} \\
* \\
{[7.96]}\end{array}$ & $\begin{array}{c}0.91 * * \\
{[1.85]}\end{array}$ & $\begin{array}{l}0.79 * \\
{[1.35]}\end{array}$ \\
\hline Model 7 & $\begin{array}{c}202.19 * * * \\
{[5.00]}\end{array}$ & $\begin{array}{c}-16.73 * * \\
{[-2.04]}\end{array}$ & $\begin{array}{l}13.20 \\
{[0.44]}\end{array}$ & $\begin{array}{c}-220.54 \\
{[-0.74]}\end{array}$ & $\begin{array}{l}75.27 \\
{[1.17]}\end{array}$ & $\begin{array}{c}-104.76 \\
{[-0.42]}\end{array}$ & $\begin{array}{c}4.95 \\
{[0.90]}\end{array}$ & $\begin{array}{l}39.60 * \\
{[1.29]}\end{array}$ \\
\hline
\end{tabular}

Not: Modellerdeki değişen varyans ve otokorelasyon sorunları White yöntemiyle giderilmiştir. ${ }^{*},{ }^{* *}$ ve ${ }^{* * *}$; ilgili parametrenin sırasıyla \%10, \%5 ve \%1 düzeyinde güvenilir olduğunu ifade etmektedir. Modellere kukla değişken eklendiği için rassal etkiler tahminlerinde Wallace-Hussain yöntemi kullanılmıştır. $@$; Petrol fiyatları bütün yatay kesitlerde aynı olduğu için bu modellerde sabit etkiler yöntemiyle tahmin yapılamamıştır. ‡; Kukla değişken modele dâhil edildiğinde matrisin tersi alınamadığı için katsayı tahmini gerçekleştirilememiş, bu nedenle sabit etkiler tahminleri kukla değişkensiz yapılmıştır. Köşeli parantez içindeki değerler $t$ istatistikleridir.

Model 1'de petrol fiyatlarındaki \%1'lik artş̧ın reel efektif döviz kurunu \%0.05 oranında azalttğı görülmüştür. Bu durum, söz konusu ülkelerde Hollanda Hastalığının olmadığını ima etmektedir Elde edilen bu sonuç literatürdeki Mercan ve Göçer (2014) çalışmasıyla uyumludur. Model 2'de artan doğal kaynak 
gelirlerinin reel efektif döviz kurunu artırdığı görülmektedir. Bu durum Hollanda Hastalığının varlığına işaret eder. Model 3'te doğal kaynak gelirleri \%1 arttğında işsizliğin \%0.24 ile \%0.63 puan arasında azaldığı görülmüştür. Bu durum; Orta Asya Türk Cumhuriyetlerinde henüz Hollanda Hastalığı sürecinin tam olarak başlamadığını, ülkelerin şimdilik, doğal kaynakların olumlu etkilerini yaşadığını düşündürmektedir. Model 4'te doğal kaynak geliri \%1 arttğında enflasyon \%5.11 puan artmaktadır. Bu da Hollanda Hastalığının bir çeşidini oluşturmaktadır ve hastalığının bir öncü göstergesidir. Model 5'te petrol fiyatlarındaki \%1'lik artışın ülkelerin ihracat gelirlerini ortalama \%1.12 artırdığı görülmüştür. Bu durum, söz konusu ülkelerin petrol ihracatna dayalı bir ekonomik yapıya sahip oldukları fikrini desteklemektedir. Model 6 'da artan reel efektif döviz kuruna karşın ihracatın da artması, iktisat teorisine zıt bir durumdur. Bu artş̧ın nedeninin; Orta Asya Türk Cumhuriyetlerinin ihraç ettiği enerji ve doğal kaynakların, karşı ülkeler için zorunlu mal konumunda olması ve reel kurdaki artşlardan etkilenmemesi olduğu değerlendirilmiştir. Model 7'de artan reel efektif döviz kurunun, ülkelerin dış ticaret dengesini olumsuz etkilediği görülmüştür. Elde edilen bu bulgu da söz konusu ülkelerde Hollanda Hastalığı riskinin var olduğunu düşündürmektedir.

Regresyon analizleri genel olarak değerlendirildiğinde; Orta Asya Türk Cumhuriyetlerinde Hollanda Hastalığının yaşandığına dair net kanıtlar elde edilememiştir. Ancak uzun dönemde bu hastalığın yaşanabileceğine ilişkin önemli kanıtlara ulaşıımıştır. Ayrıca artan doğal kaynak ihracatının, bu ülkelerde enflasyonu arttırdığı ve reel efektif döviz kuru üzerinden dış ticaret dengesini olumsuz etkilediği tespit edilmiştir. İlgili ülke yöneticilerinin şimdiden gerekli önlemleri almalarında yarar vardır.

\subsection{Panel Nedensellik Testi}

Seriler arasındaki nedensellik ilişkileri Dumitrescu ve Hurlin (2012) testiyle incelenmiştir. Bu yöntem; ülkeler arasındaki yatay kesit bağımlıı̆ı̆nı göz önünde bulundurabilmektedir. Testin boş hipotezi 'nedensellik ilişkisi yoktur' şeklindedir. Çalışmada Dumitrescu ve Hurlin (2012) nedensellik testi sonuçları Tablo 7'de sunulmuştur.

Tablo 7. Panel Nedensellik Testi Sonuçları

\begin{tabular}{|c|c|c|c|c|c|c|}
\hline Boş Hipotez & Lag & Kriter & $\begin{array}{c}W \\
\text { istatistiği }\end{array}$ & $\begin{array}{c}\bar{Z} \\
\text { i istatistiği } \\
\end{array}$ & $\begin{array}{l}\text { Olasılık } \\
\text { Değeri }\end{array}$ & Karar \\
\hline $\begin{array}{l}\text { Poil } \nRightarrow \text { REER } \\
\text { REER } \nRightarrow \text { Poil }\end{array}$ & 1 & $\begin{array}{l}\text { LR, FPE, } \\
\text { HQ }\end{array}$ & $\begin{array}{l}23.791 \\
1.083\end{array}$ & $\begin{array}{l}29.460 \\
-0.107\end{array}$ & $\begin{array}{c}0.000 * * * \\
0.914\end{array}$ & $\begin{array}{l}\text { Petrol fiyatlarından, reel efektif döviz kuruna } \\
\text { doğru tek yönlü nedensellik ilişkisi vardır. }\end{array}$ \\
\hline $\begin{array}{l}D K G \nRightarrow R E E R \\
R E E R \nRightarrow D K G\end{array}$ & 2 & $\begin{array}{l}\text { LR, FPE, } \\
\text { AIC, HQ }\end{array}$ & $\begin{array}{l}4.950 \\
2.472 \\
\end{array}$ & $\begin{array}{l}2.003 \\
0.022\end{array}$ & $\begin{array}{c}0.045^{* *} \\
0.982\end{array}$ & $\begin{array}{l}\text { Doğal kaynak gelirlerinden reel efektif döviz } \\
\text { kuruna doğru tek yönlü nedensellik ilişkisi vardır. }\end{array}$ \\
\hline $\begin{array}{l}U N \nRightarrow D K G \\
D K G \nRightarrow U N\end{array}$ & 1 & $\begin{array}{l}\text { LR, FPE, } \\
\text { AIC, HQ }\end{array}$ & $\begin{array}{l}1.028 \\
6.035\end{array}$ & $\begin{array}{l}-0.179 \\
6.339\end{array}$ & $\begin{array}{c}0.857 \\
0.002 * * *\end{array}$ & $\begin{array}{l}\text { Doğal kaynak gelirlerinden işsizlik oranına doğru } \\
\text { tek yönlü nedensellik ilişkisi vardır. }\end{array}$ \\
\hline $\begin{array}{l}P \nRightarrow D K G \\
D K G \nRightarrow P\end{array}$ & 1 & $\begin{array}{l}\text { LR, FPE, } \\
\text { AIC, HQ }\end{array}$ & $\begin{array}{l}1.891 \\
1.226\end{array}$ & $\begin{array}{l}0.943 \\
0.078\end{array}$ & $\begin{array}{l}0.345 \\
0.937\end{array}$ & $\begin{array}{l}\text { Enflasyonla doğal kaynak geliri arasında } \\
\text { nedensellik ilişkisi yoktur. }\end{array}$ \\
\hline $\begin{array}{l}X \nRightarrow \text { Poil } \\
\text { Poil } \nRightarrow X\end{array}$ & 1 & $\begin{array}{l}\text { LR, FPE, } \\
\text { AIC, HQ }\end{array}$ & $\begin{array}{l}2.151 \\
1.713\end{array}$ & $\begin{array}{l}1.281 \\
0.712\end{array}$ & $\begin{array}{l}0.199 \\
0.476\end{array}$ & $\begin{array}{l}\text { Petrol fiyatları ile ihracat arasında nedensellik } \\
\text { ilişkisi yoktur. }\end{array}$ \\
\hline $\begin{array}{l}X \nRightarrow R E E R \\
R E E R \nRightarrow \operatorname{Ln} X\end{array}$ & 2 & $\begin{array}{l}\text { LR, FPE, } \\
\text { AIC, HQ }\end{array}$ & $\begin{array}{l}6.394 \\
3.919\end{array}$ & $\begin{array}{l}3.157 \\
1.179\end{array}$ & $\begin{array}{c}0.001 * * * \\
0.238\end{array}$ & $\begin{array}{l}\text { Ihracattan reel efektif döviz kuruna doğru bir } \\
\text { nedensellik ilişkisi vardır. }\end{array}$ \\
\hline $\begin{array}{l}X / M \nRightarrow R E E R \\
R E E R \nRightarrow X / M\end{array}$ & 1 & $\mathrm{SC}, \mathrm{HQ}$ & $\begin{array}{l}6.917 \\
1.776\end{array}$ & $\begin{array}{l}7.487 \\
0.794\end{array}$ & $\begin{array}{c}0.000 * * * \\
0.427\end{array}$ & $\begin{array}{l}\text { Dış ticaret dengesinden reel efektif döviz kuruna } \\
\text { doğru bir nedensellik ilişkisi vardır. }\end{array}$ \\
\hline
\end{tabular}

Not: ${ }^{*},{ }^{*}$ ve ${ }^{* * *}$; birinci değişkenden ikinci değişkene doğru sırasıyla $\% 10, \% 5$ ve $\% 1$ önem düzeyinde istatistiksel olarak güvenilir bir nedensellik ilişkisinin var olduğunu ifade etmektedir. LR: Lagrange Ratio, FPE: Final Prediction Error, AIC: Akaike Information Criterion, SC: Schwarz Criterion, HQ: Hannan-Quinn. 
Tablo 7'deki ilk testte; petrol fiyatlarından, reel efektif döviz kuruna doğru tek yönlü nedensellik ilişkisinin var olması; söz konusu ülkelerde Hollanda Hastalığının varlığına işaret etmektedir. íkinci testte doğal kaynak gelirlerinden reel efektif döviz kuruna doğru olan nedensellik ilişkisi de Hollanda Hastalığına varlığına ikinci delildir. Üçüncü testte doğal kaynak gelirlerinden işsizlik oranına doğru belirlenen nedensellik ilişkisi de Hollanda Hastalığının varlığı fikrini desteklemektedir. Altıncı testteki ihracattan reel efektif döviz kuruna doğru belirlenen nedensellik ilişkisi de Hollanda Hastalığının varlığına ek bir delil teşkil etmektedir. Son testteyse dış ticaret dengesinden reel efektif döviz kuruna doğru bir nedensellik ilişkisi vardır. Bu da Hollanda Hastalığının bir sonucudur.

\section{Sonuç ve Politika Önerileri}

Orta Asya Türk Cumhuriyetleri önemli miktarda petrol, doğal gaz ve maden yataklarına sahip bulunmaktadır. Ancak sadece doğal kaynak ihracatına dayalı bir ekonomik model sürdürülebilir değildir. Böyle bir süreç, başta Hollanda Hastalığı olmak üzere pek çok ekonomik sorunu da beraberinde getirebilecektir.

Çalışmada Orta Asya Türk Cumhuriyetlerinde Hollanda Hastalığı riski ve bunun, ülkelerin ihracat performansına etkileri, 1998-2015 dönemi için panel veri analiziyle araştırılmıştır. Ülkeler arasında yatay kesit bağımlılığı tespit edildiği için ikinci nesil panel veri analiz yöntemleri kullanılmıştr. Serilerin durağanlığı PANKPSS çoklu yapısal kırılmalı birim kök testi yapılmış ve serilerin düzeyde durağan olduğu belirlenmiştir.

Serilerin tamamı düzeyde durağan bulunduğu için eşbütünleşme testine ve ona uygun tahmincilerin kullanımına imkân kalmamış, bu nedenle regresyon analizine geçilmiştir. Regresyon analizleri, muhtemel bütün durumları göz önünde bulundurabilmek için; havuzlanmış $E K K$, sabit etkiler modeli ve rassal etkiler modeliyle ayrı ayrı gerçekleştirilmiştir. Regresyon analizleri genel olarak değerlendirildiğinde; Orta Asya Türk Cumhuriyetlerinde Hollanda Hastalığının yaşandığına dair net kanıtlar elde edilememiştir. Ancak uzun dönemde bu hastalı̆̆ın yaşanabileceğine ilişkin önemli kanıtlara ulaşıımıştır. Ayrıca artan doğal kaynak ihracatının, bu ülkelerde enflasyonu arttırdığı ve reel efektif döviz kuru üzerinden dış ticaret dengesini olumsuz etkilediği tespit edilmiştir. İlgili ülke yöneticilerinin şimdiden gerekli önlemleri almalarında fayda vardır.

Nedensellik analizi sonucunda; petrol fiyatlarından, ihracattan, doğal kaynak gelirlerinden ve dış ticaret dengesinden reel efektif döviz kuruna ve doğal kaynak gelirlerinden işsizlik oranına doğru tek yönlü nedensellik ilişkileri tespit edilmiştir ki bu durum, söz konusu ülkelerde Hollanda Hastalığının varlığına işaret etmektedir. Petrol fiyatları ile ihracat arasında bir nedensellik ilişkisinin olmamasının, Orta Asya Türk Cumhuriyetlerinin sadece petrol değil, başta doğal gaz olmak üzere pek çok yer alt kaynağı satmasından kaynaklandığı değerlendirilmiştir.

Çalışmadan elde edilen bulgulara dayanarak; Orta Asya Türk Cumhuriyetlerinde doğal kaynakların işlenmeden satıımasına ve elde edilen gelirlerin etkin değerlendirilememesine bağlı olarak Hollanda Hastalığı riskinin olduğu söylenebilir. Bu ülkelerin, sahip oldukları doğal kaynakları işlemeden satmak yerine, Ar-Ge ve inovasyona dayalı yöntemlerle işleyip, katma değerini artırarak ihraç etmelerinde ve elde edilen döviz gelirlerini, uzun vadeli planlamalara göre değerlendirmelerinde yarar vardır. Bu sayede istihdam artacak, nitelikli işgücü yetişecek, ülkelerin sabit sermaye stoku ve sanayi sektörü gelişecektir. Ülkeler iç ve dış ekonomik şoklara karşı daha dayanıklı hale geleceklerdir.

Yöneticilerin, doğal kaynakların sınırsız olmadığını, günün birinde biteceğini de göz önüne alıp, Hollanda ve Dubai örneklerinde olduğu gibi ekonomilerini çeşitlendirmelerinde yarar vardır. Ayrıca doğal kaynakların fiyatı uluslararası piyasalarda belirlendiği için, bu fiyatlarda meydana gelen dalgalanmalar, küçük ulusal ekonomileri zor durumda bırakabilecektir. Buna karşı Norveç örneğinde olduğu gibi gelir fonları oluşturulup, doğal kaynağın bol ve fiyatının yüksek olduğu dönemlerde, elde edilen gelirin önemli bir kısmını bu fonlara devredip, fonları da şeffaf ve verimli bir şekilde değerlendirmekte fayda vardır.

Çok önemli bir nokta da Arap Ülkelerinde görüldüğü üzere, doğal kaynak satı̧̧ından elde edilen gelirin dar bir kesim tarafindan kullanılması ve geniş halk kitlelerinin bundan mahrum bırakılmasının yol açabileceği sosyal ve siyasal patlamalardır. 2010 yılında Tunus'ta başlayarak 27 Arap Ülkesini etkisi altına alan, Yemen ve 
Suriye'de hala etkileri görülen bu tür olaylar, ülkelerin siyasi ve ekonomik istikrarına önemli zararlar verebilmektedir. Bu nedenle devleti yönetenlerin dikkatli davranmaları, doğal kaynakların ortak kamu malı olduğunu, buradan elde edilen refahın tüm yurttaşlarla eşit paylaşılması gerektiğini bu kaynaklarda sadece şimdiki nesillerin değil, gelecek nesillerin de haklarının olduğunu unutmayarak, uzun vadeli ve sürdürülebilir politikalar geliştirmeleri gerekmektedir.

\section{Son Notlar}

1. Bu çalışmada verilere ulaşmada çok ciddi zorluklar yaşanmıştr. Dünya Bankası, IMF, Asya Kalkınma Bankası, ülkelerin merkez bankası ve istatistik ofisleri defalarca taranmış, yetkililere ve bu konuda çalışması olan yazarlara mailler gönderilmiştir. Orta Asya Türk Cumhuriyetlerinin, çağdaş dünyaya entegre olabilmesi ve bilimsel çalışmalara konu edilebilmesi için veri setlerini düzenli hale getirmeleri ve uluslararası veri bankalarıla eş anlı paylaşılmaları gerekmektedir. Böyle bir çabanın asıl yararını, yine bu ülkelerin yöneticileri görecektir. Çünkü "ölçemediğiniz şeyi yönetemezsiniz" prensibi gereği, önce kendileri ekonomilerindeki temel büyüklüklerinin nereye gittiğini görebilmelidirler ki, doğru politikalar belirleyebilsinler.

2. Bu ülkelerin reel efektif döviz kuruna ulaşmada ciddi güçlüklere karşılaşılmış, yapılan araştırmalarda Darvas (2012) çalışmasına ulaşılımıştr. Yazara maille ulaşılıp veri seti rica edilmiş ve gönderdiği linkten bu veri setinin en güncel haline erişilmiştir. Yaptiğı değerli çalışma ve paylaşıma kişiliğinden dolayı Macaristan Corvinus University'den Yrd. Doç. Dr. Zsolt Darvas'a teşekkürlerimi sunuyorum. Bu link çalışmanın kaynakçasında paylaşılarak, diğer araştırmacılara önemli bir kolaylık sağlanmıştır.

3. Analiz kapsamında onlarca farklı model tahmin edilmiş, en anlamlı ilişki veren modeller buraya alınmıştır.

\section{Kaynaklar}

Akça, E.E., \& Bal, H. (2017). Yurtdışı iş̧̧i gelirlerinin makroekonomik etkileri ve Hollanda Hastalı̆ı. V. Anadolu International Conference in Economics, May 11-13, 2017, Eskişehir, Turkey.

Akçacı, T., \& Karaata, A. (2014). Türkiye'de uluslararası fonların paradoksal etkisi: Hollanda Hastalığı. International Conference on Eurasian Economies, 1-3 July, Skopje, Macedonia.

Aljazeera (2012). Kronoloji: Yunanistan'ın borç krizi. http://www.aljazeera.com.tr/haber-analiz/kronoloji-yunanistaninborc-krizi (Erişim Tarihi, 05 Mart 2017).

Arı, A., \& Özcan, B. (2012). Hollanda Hastalığı: Gelişmekte olan ülkeler üzerine bir uygulama. Sosyoekonomi, 2, 153-172.

Asian Development Bank (2017). Key indicators for Asia and the Pacific 2016. https://www.adb.org/publications/keyindicators-asia-and-pacific-2016 (Erişim Tarihi, 6 Mart 2017).

Akça, E. E., Bal, H., \& Demiral, M. (2015). Doğal kaynak zenginliği ve ekonomik büyüme ilişkisinde yönetişim göstergelerinin araclık etkisi: MENA ve Hazar ülkelerinden ampirik bulgular. Ege Akademik Bakış, 15(3), 301-312.

Bacak, Ç. (2014). Hollanda Hastalığının (Dutch Disease) alternatif yorumu, sanayisizleşme ve çıkış yolları. Kalkınmada Anahtar Verimlilik Dergisi, 302. http://anahtar.sanayi.gov.tr/tr /news/hollanda-hastaliginin-dutch-diseasealternatif-yorumu-sanayisizlesme-ve-cikis-yollari/692 (Erişim Tarihi, 13 Eylül 2017).

Baltagi, B. H, Feng, Q., \& C. Kao (2012). A lagrange multiplier test for cross-sectional dependence in a fixed effects panel data model. Journal of the Econometrics, 170, 164-177.

Bature, B. N. (2013). The Dutch Disease and the diversification of an economy: Some case studies. Journal of Humanities and Social Science, 15(5), 6-14.

Berikan, M., \& Hüseyinli, T. (2017). Petrol fiyatlarındaki düşüşün Rusya ekonomisi üzerine etkileri. iktisadi Yenilik Dergisi, $4(2), 30-45$.

BP (2016). Statistical review of world energy june, https://www.bp.com/content/ dam/bp/pdf/energyeconomics/statistical-review-2016/bp-statistical-review-of-world-energy-2016-full-report.pdf (Erişim Tarihi, 09 Mart 2017).

Breusch, T.S., \& Pagan, A.R. (1980). The lagrange multiplier test and its applications to model specification tests in econometrics. Review of Economic Studies, 47, 239-53. 
Broz, T., \& Dubravcic, D. (2011). The Dutch Disease in unwonted places -why has Croatia been infected while Slovenia remains in good health? South Eastern Europe Journal of Economics, 1, 47-66.

Bulut, C., \& Suleymanov, E. (2012). Importance of economic collaboration between Azerbaijan and Turkey in preventing Dutch Disease in Azerbaijan. International Symposium on Regional Cooperation and Development, October 1720, Erzurum, Turkey.

Carrion-i-Silvestre, J. L., Barrio-Castro, T. D., \& Lopez-Bazo, E. (2005). Breaking the panels: An application to the GDP per capita. 8, 59-175.

Corden, W. M., \& Neary, J. P. (1982). Booming sector and de-industrialization in a small open economy. Economic Journal, 92(368), 825-848.

Darvas, Z. (2012). Real effective exchange rates for 178 countries: A new database. Bruegel WP, No: 06.

Darvas, Z. (2017). Real effective exchange rates for 178 countries: A new database. http://bruegel.org/publications/datasets/real-effective-exchange-rates-for-178-countries-a-new-database/ (Erişim Tarihi, 10 Mart 2017).

Data Market, (2017). Price level of Turkmenistan, https://datamarket.com/data/set/41az/ price-level-of-investmentfor-turkmenistan\#!ds= 41az\&display=line (Erişim Tarihi, 09 Mart 2017).

Demirtepe, M.T. (2008), Orta Asya ve Kafkasya'da güç politikası. Ankara: USAK Yayınları, No:16.

Dumitrescu, E., \& Hurlin, C. (2012). Testing for granger non-causality in heterogeneous panels. Economic Modelling, 29(4), 1450-1460.

Dünya Bankası (2015). Low commodity prices and weak currencies. World Bank ECA Economic, Office of the Chief Economist.

Ebrahimzadeh, C. (2012). Dutch Disease: Wealth managed unwisely. IMF, Finance \& Development, http://www.imf.org/external/pubs/ft/fandd/basics/dutch.htm (Erişim Tarihi, 05 Mart 2017).

Erkut, F. (2015). Hollanda enerji sektör raporu. İzmir Ticaret Odası.

Gelb, A. (1988). Windfall gains: Blessing or curse?, Oxford University Press, New York.

Gerçeğin Günlüğü (2010). Tembel Yunan işçisi efsanesi. http://gercegingunlugu.blogspot.com.tr/2010/05/tembelyunan-iscisi-efsanesi.html (Erişim Tarihi, 5 Mart 2017).

Gregory, R. G. (1976). Some implications of the growth of the mineral sector. Australian Journal of Agricultural Economics, 20, 72-91.

Göçer, i., \& Çınar, S. (2015). Arap Baharı'nın nedenleri, uluslararası ilişkiler boyutu ve Türkiye'nin dış ticaret ve turizm gelirlerine etkileri. Kafkas Üniversitesi IiBF Dergisi, 6(10), 51-68.

Hasanov, F., \& Samadova, I. (2010). The impact of real effective exchange rate on the non-oil export: The case of Azerbaijan. https://papers.ssrn.com/sol3/papers.cfm?abstract_id=1784286 (Erişim Tarihi, 11 Mayıs 2017).

Hasanov, F. (2010). The impact of real oil price on real effective exchange rate: The case of Azerbaijan. DIW Berlin, German Institute for Economic Research, DP, No: 1041.

Hasanov, R. (2017). Assessment on real effective exchange rate in Azerbaijan: 2017 outlook. CESD Press, Januray.

Hoen, H. W. (2010). Transition strategies in Central Asia: Is there such a thing as "shock-versus-gradualism? Economic and Environmental Studies, 10(2), 229-245.

IMF (2016). World Economic Outlook Database, October.

Lederman, D., \& Maloney, W. F. (2008). In search of the missing resource curse. World Bank Policy Research, WP, No: 4766.

Magud, N., \& Sosa, S. (2014). Managing economic volatility in Latin America. IMF Publication, Editor: R.G. Gelos.

Mankiw, N. G. (2010), Makroekonomi. Çev. Editörü: Ö. Faruk Çolak, Ankara: Efil Yayınevi.

Mercan, M., \& Göçer, İ. (2014). Orta Asya Türk Cumhuriyetlerinde Hollanda Hastalığı Riski: Ampirik bir analiz. Hacettepe Üniversitesi IiBF Dergisi, 32(2), 251-274.

Mironov, V., \& Petronevich, A. (2015). Discovering the signs of Dutch disease in Russia. Resources Policy, 46(2), 113126.

National Geographic (2013). The Palm Island, Dubai UAE - Megastructure development. https://www.youtube.com/watch?v=0BXGh0EYJtE (Erişim Tarihi, 06 Haziran 2017).

Oomes, N., \& Kalcheva, K. (2007). Diagnosing Dutch Disease: Does Russia have the symptoms?. IMF WP, No: 102. 
Onur, G. (2011). Birleşik Arap Emirlikleri Ülke Raporu. T.C. Başbakanlık Dış Ticaret Müsteşarlığı Ihracatı Geliştirme Etüd Merkezi.

Quandl, (2017a). Uzbekistan Inflation Index, Average Consumer Prices.

Quandl, (2017b). Tajikistan Inflation Index, Average Consumer Prices.

Pesaran, M.H. (2004). General diagnostic tests for cross section dependence in panels. Cambridge Working Papers in Economics, N. 435.

Rodriguez, C. M. (2006). Dutch Disease in Saudi Arabia?. Lund University, Department of Economics, Master's Thesis.

Sachs, J. D., \& Warner, A. M. (2001). The curse of natural resources. European Economic Review, 45(4), 827-838.

Sala-i-Martin, X., \& Subramanian, A. (2003). Addressing the natural resource curse: An illustration from Nigeria. IMF WP, No: 139.

Sevinçer, V. (2009). Bir ülke petrolle nasıl zengin olmaz? Norveç, petrol ve eğitimli insan gücü faktörü. BiLGESAM.

Smith, B. (2014). Dutch Disease and the oil and boom and bust. http://www.oxcarre.ox.ac.uk/images/stories/papers/ResearchPapers/oxcarrerp2014133.pdf (Erişim Tarihi, 6 Haziran 2017).

Şahin, L., \& Kutluay Şahin, D. (2015). The effects of Dutch Disease: Case of Russia. Hitit University Journal of Social Sciences Institute, 8(2), 599-610.

The Economist (2014). What Dutch Disease is, and why it's bad. http://www.economist.com/blogs/economistexplains/2014/11/economist-explains-2 (Erişim Tarihi, 05 Nisan 2017).

Ueno, P. H. (2010). Can Dutch Disease harm the export performance of Brazilian industry?. DRUID Summer Conference, London, UK.

World Bank (2017a), Total Natural Resources Rents (\% of GDP).

World Bank (2017b),. Exports of Goods and Services (Current US\$).

World Bank (2017c), GDP (current US\$).

World Bank (2017e),. Agricultural Raw Materials Exports (\% of Merchandise Exports).

World Bank (2017f),. Merchandise Exports (Current US\$).

World Bank (2017h), High-Technology Exports (\% of Manufactured Exports).

World Bank (2017i), Population, Total.

World Bank (2017j, GDP Growth (Annual \%).

World Bank (2017k), GDP Per Capita (Current US\$).

World Bank (2017m),. Merchandise Imports (Current US\$).

World Bank (2017n), Unemployment (\% of Total Labor Force).

World Bank, (2017p), Inflation, Consumer Prices (Annual \%).

Yıldırım, K., Karaman, D., \& Taşdemir, M. (2009). Makroekonomi. Sekizinci Basım. Ankara: Seçkin Yayıncılık.

Yıldırım, M. N., \& Gurbanov, S. (2013). Azerbaycan`da enerji kaynakları sektöründe yaşanan Hollanda Hastalığı’nın makroekonomik etkileri: Karşılaştırmalı analiz. EconAnadolu, 19-21, June, Eskişehir.

Yürük, M. S. (2008). Kaynakların laneti olgusu: Rusya örneği. Trakya Üniversitesi Sosyal Bilimler Enstitüsü, Yayımlanmamış Yüksek Lisans Tezi, Edirne. 